\title{
Long-term safety of growth hormone therapy: still a controversial issue
}

\author{
Stefano Cianfarani* \\ Department of Systems Medicine, Tor Vergata University and Molecular Endocrinology Unit-Bambino Gesù Children's Hospital, Rome, Italy \\ *Correspondence: stefano.cianfarani@uniroma2.it \\ Edited by: \\ Ze'Ev Hochberg, Technion-Israel Institute of Technology, Israel
}

\section{A commentary on}

Long-term mortality after recombinant growth hormone treatment for isolated growth hormone deficiency or childhood short stature: preliminary report of the French SAGhE study

by Carel, J. C., Ecosse, E., Landier, F., Meguellati-Hakkas, D., Kaguelidou, F., Rey, G., and Coste, J. (2012). J. Clin. Endocrinol. Metab. 97, 416-425.

Substantial experimental evidence supports the involvement of growth hormone (GH) and, especially, its main effector insulin-like growth factor-I (IGF-I) in the development, growth, and dissemination of several types of cancer (Cianfarani and Rossi, 1997; Holly et al., 1999, Renehan et al., 2004; Clayton et al., 2011). However, although the data from in vitro and in vivo studies are robust, the evidence in humans is weak (Clayton et al., 2011).

Growth hormone extracted from human pituitaries (hGH) became available for therapy of GH deficient children in early 1960s. In 1985, following the reports of an association of this treatment with the occurrence of Creutzeldt-Jakob disease, human GH was banned and replaced by recombinant hGH (rhGH). Since then, due to the unlimited supply of this molecule, the indications for rhGH have greatly expanded worldwide, now including childhood and adult GH deficiency, Turner syndrome, chronic renal failure, small for gestational age (SGA), Prader-Willi syndrome, Noonan syndrome, SHOX deficiency, idiopathic short stature (ISS), and AIDS wasting. Despite a so long time of use in so many different clinical conditions, rhGH has rarely been associated with the occurrence of serious side effects. However, longitudinal studies aimed at evaluating the health of adult subjects treated with rhGH during childhood are few and often not independent of Pharmaceutical Companies. Nevertheless, an association of hGH or rhGH treatment with a higher incidence of cancer (Swerdlow et al., 2002) and type 2 diabetes (Cutfield et al., 2000; Child et al., 2011) has been reported.

The recent publication of two studies stemming from SAGhE (Safety and Appropriateness of $\mathrm{GH}$ treatments in Europe) European consortium, which was started in 2009 and includes eight countries (France, Sweden, Belgium, the Netherlands, Switzerland, Germany, United Kingdom, and Italy), has generated confusion and

controversy rather than shedding light on this delicate matter (Carel et al., 2012; Sävendahl et al., 2012). The French study reported a significant increase in both allcause mortality and specific mortality for bone tumors or cerebral hemorrhage in a cohort of about 6500 young adult subjects treated with rhGH during childhood for GH deficiency, SGA, or ISS (Table 1). On the basis of these findings, in 2010 the EMA's Committee for Medicinal Products for Human Use (CHMP) launched a warning aimed at narrowing the dose range used in the different indications approved in Europe and started a review of all available data to

Table 1 | Preliminary data reported from SAGhE (Safety and Appropriateness of Growth hormone treatments in Europe) project.

\begin{tabular}{|c|c|c|c|c|}
\hline France & Neoplasms & Observed & Expected & SMR (95\% Cl) \\
\hline & All-cause & 7 & 6.89 & $1.02(0.41-2.09)$ \\
\hline & $\begin{array}{l}\text { Malignant neoplasm } \\
\text { of bone and articular } \\
\text { cartilage }\end{array}$ & 3 & 0.60 & $5.00(1.01-14.61)$ \\
\hline & $\begin{array}{l}\text { Cerebrovascular } \\
\text { diseases }\end{array}$ & 4 & 0.76 & $5.29(1.42-13.55$ \\
\hline
\end{tabular}

\begin{tabular}{lll}
\hline Sweden, The Netherlands, Belgium & Cause of death & Number of deaths \\
\hline & Traffic accident & 5 \\
Accident & 2 \\
Suicide & 4 \\
Homicide & 1 \\
Poisoning & 4 \\
Pneumonia & 1 \\
Other Endocrine Dysfunction & 1 \\
Primary cardiomyopathy & 1 \\
Immune deficiency & 1 \\
Coagulation defect & 1 \\
Cancer & 0 \\
Cerebrovascular diseases & 0
\end{tabular}

Data are expressed in Standardized Mortality Ratio (SMR) for France, and absolute number of deaths for Sweden, The Netherlands and Belgium. 
assess the risk-benefit balance. In contrast to the French data, the other study involving patients from Sweden, The Netherlands, and Belgium, reported not a single case of death from cancer or cerebrovascular disease in about 2500 subjects with the same diagnoses (Table 1).

Both studies show a series of potential biases such as the relative small sample size, the low event rate, the lack of an untreated control group available for comparison, and the lack of reference data in the age groups including height. In addition, it is hard to explain the opposite results. Differences in genetics, environment, or, more simply, confounding factors might account for the discrepancy between the two SAGhE sub-studies.

Due to the large number of individuals treated with rhGH nowadays, it is urgent to obtain definitive data on the safety of this therapy. The SAGhE project is due to finish in November 2012 and the analysis of the whole cohort (about 25,000 subjects) will provide more complete and robust data. These two preliminary SAGhE reports have undoubtedly the merit to stress the importance to replicate these surveys in different contexts, and to provide the methodological background for a joint effort involving all the stakeholders (physicians, regulatory agen- cies, pharmaceutical companies, patients, and their families), to invest resources and expertise in setting up an international task force aimed at addressing this still controversial issue (Rosenfeld et al., 2012).

\section{REFERENCES}

Carel, J. C., Ecosse, E., Landier, F., Meguellati-Hakkas, D., Kaguelidou, F., Rey, G., and Coste, J. (2012). Longterm mortality after recombinant growth hormone treatment for isolated growth hormone deficiency or childhood short stature: preliminary report of the French SAGhE study. J. Clin. Endocrinol. Metab. 97, 416-425.

Child, C. J., Zimmermann, A. G., Scott, R. S., Cutler, G. B., Battelino, T., Blum, W. F., and Board, G. I. A (2011). Prevalence and incidence of diabetes mellitus in GH-treated children and adolescents: analysis from the GeNeSIS observational research program. J. Clin. Endocrinol. Metab. 96, E1025-E1034.

Cianfarani, S., and Rossi, P. (1997). Neuroblastoma and insulin-like growth factor system. New insights and clinical perspectives. Eur. J. Pediatr. 156, 256-261.

Clayton, P. E., Banerjee, I., Murray, P. G., and Renehan, A. G. (2011). Growth hormone, the insulin-like growth factor axis, insulin and cancer risk. Nat. Rev. Endocrinol. 7, 11-24.

Cutfield, W. S., Wilton, P., Bennmarker, H., AlbertssonWikland, K., Chatelain, P., Ranke, M. B., and Price, D. A. (2000). Incidence of diabetes mellitus and impaired glucose tolerance in children and adolescents receiving growth-hormone treatment. Lancet 355, 610-613.

Holly, J. M., Gunnell, D. J., and Davey Smith, G. (1999). Growth hormone, IGF-I and cancer. Less intervention to avoid cancer? More intervention to prevent cancer? J. Endocrinol. 162, 321-330.
Renehan, A. G., Zwahlen, M., Minder, C., O’Dwyer, S. T., Shalet, S. M., and Egger, M. (2004). Insulin-like growth factor (IGF)-I, IGF binding protein-3, and cancer risk: systematic review and meta-regression analysis. Lancet 363, 1346-1353.

Rosenfeld, R. G., Cohen, P., Robison, L. L., Bercu, B. B. Clayton, P., Hoffman, A. R., Radovick, S., Saenger, P., Savage, M. O., and Wit, J. M. (2012). Long-term surveillance of growth hormone therapy. J. Clin. Endocrinol. Metab. 97, 68-72.

Sävendahl, L., Maes, M., Albertsson-Wikland, K., Borgström, B., Carel, J. C., Henrard, S., Speybroeck, N., Thomas, M., Zandwijken, G., and HokkenKoelega, A. (2012). Long-term mortality and causes of death in isolated GHD, ISS, and SGA patients treated with recombinant growth hormone during childhood in Belgium, The Netherlands, and Sweden: preliminary report of 3 countries participating in the EU SAGhE study. J. Clin. Endocrinol. Metab. 97, E213-E217.

Swerdlow, A. J., Higgins, C. D., Adlard, P., and Preece, M. A. (2002). Risk of cancer in patients treated with human pituitary growth hormone in the UK, 195985: a cohort study. Lancet 360, 273-277.

Received: 02 September 2012: accepted:04 September 2012; published online: 19 September 2012.

Citation: Cianfarani S (2012) Long-term safety of growth hormone therapy: still a controversial issue. Front. Endocrin. 3:115. doi:10.3389/fendo.2012.00115

This article was submitted to Frontiers in Pediatric Endocrinology, a specialty of Frontiers in Endocrinology. Copyright (c) 2012 Cianfarani. This is an open-access article distributed under the terms of the Creative Commons Attribution License, which permits use, distribution and reproduction in other forums, provided the original authors and source are credited and subject to any copyright notices concerning any third-party graphics etc. 